Original Research Paper

\title{
Utilization of Forest Plants as Local Food Sources for the Oben Village Community, Nekamese District, Kupang Regency
}

\author{
Nur Aini Bunyani1 ${ }^{*}$, Maya Roman', Jorita Naisanu ${ }^{1}$ \\ ${ }^{1}$ Universitas Persatuan Guru 1945 NTT
}

\author{
Article History \\ Received : July $27^{\text {th }}, 2020$ \\ Revised : August $05^{\text {th }}, 2020$ \\ Accepted : September $05^{\text {th }}, 2020$ \\ Published : October $14^{\text {th }}, 2020$ \\ *Corresponding Author: \\ Nur Aini Bunyani, \\ Universitas Persatuan Guru 1945 \\ NTT \\ Email: ainibny@gmail.com
}

\begin{abstract}
Forest plants as a source of food as a substitute for carbohydrates have long been used by the village community. Forest plants directly address the food insecurity experienced by villagers. This research was conducted in Oben Village, Nekamese District, Kupang Regency on April 24 to July 22, 2018. The aim of this study was to describe the use of forest plant species as a local food source and their traditional processing by the Oben Village Community, Nekam District, Kupang Regency. These are the exploration, exploration and interview methods. The data obtained were analyzed descriptively. The results of this study were: Found 5 types of forest tubers that are commonly used by the people of Oben Village as a food source, namely Dioscorea alata L; Dioscorea esculenta L; Dioscorea hispida D; Dioscorea pentaphylla and Amorphophallus compulatus, The traditional way of processing forest tubers is that they can be washed immediately, then roasted, boiled or steamed, processed into local chips, compote and flour as cake ingredients.
\end{abstract}

Keywords: Utilization; Forest plant; Local food

\section{Pendahuluan}

Saat ini, berbagai negara di dunia mencari jalan agar mampu menghadapi masa krisis dampak pandemi Coronavirus Disease 2019 (COVID-19), termasuk menghadapi krisis pangan. Tanaman pangan telah dibudidayakan di hutan terjadi secara alamiah. Namun kontribusi kehutanan dalam mendukung ketahanan pangan tidak nyata karena pangan yang diperoleh dari hutan tidak dicatat sebagai hasil hutan. Hasil penelitian menunjukkan bahwa pemanfaatan hutan sebagai sumber pangan berlangsung secara berkelanjutan dalam 5 (lima) periode kehidupan manusia berinteraksi dengan hutan. Pada Periode I dan II, hutan menjadi sumber pangan utama atau satu-satunya. Pada Periode III, hutan menjadi tempat awal berkembangnya budidaya tanaman pangan. Pada Periode IV, tanaman pangan dibudidayakan pada saat permudaan hutan. Pada Periode $\mathrm{V}$, tanaman pangan dalam kategori pohon, palem, perdu dan tanaman semusim dibudidayakan di areal: hutan tanaman industri, hutan tanaman rakyat, hutan desa, hutan kemasyarakatan dan hutan tanaman HHBK. Berdasarkan realitas tersebut, pangan yang diperoleh dari hutan layak ditetapkan sebagai hasil hutan (Hardiyanto, B., 2020).

Hasil penelitian Diversifikasi komoditas merupakan potensi dan peluang dalam pengembangan HHBK, terutama dalam memberdayakan masyarakat yang selama ini memiliki ketergantungan terhadap produk HHBK. Dukungan penelitian dan pengembangan sangat diperlukan dalam rangka menemukan model-model pengembangan HHBK, sehingga dapat dihasilkan alternatif model pengembangan yang dapat membantu mengatasi persoalan kebutuhan dasar masyarakat untuk ketahanan pangan wilayah Timor Barat, Nusa Tenggara Timur, NTT (Njurumana dan Butarbutar, 2008). Secara langsung ataupun tidak langsung kehidupan manusia selalu berhubungan dengan tumbuhan dan tanaman untuk pemenuhan kebutuhan hidupnya, diantaranya sebagai bahan pangan. Penelitian mengenai identifikasi tanaman hutan sebagai sumber pangan lokal dan pengolahannya secara tradisional selanjutnya dapat dipergunakan untuk memenuhi kebutuhan masyarakat setempat khususnya masyrakat Desa Oben.

Hutan bagi Masyarakat NTT terutama bagi Masyarakat yang masih memiliki nilai-nilai kultur 
tradisional, bukan hal yang baru. Hal ini terjadi karena Hutan menyediakan sumber kehidupan bagi manusia seperti sandang pangan, papan dan obat-obatan. Masyarakat NTT khususnya masyarakat yang tinggal di daerah pedalaman / pedesaan kehidupannya masih sangat tergantung pada sumber daya yang ada di hutan dan disekitar tempat tinggal. Desa Oben Kecamatan Nekamese Kabupaten Kupang (Timor Barat) merupakan salah satu desa di NTT yang memiliki kawasan hutan yang sangat luas, oleh masyarakat masyarakat setempat hutan dijadikan sebagai tempat untuk mendapatkan bahan-bahan kebutuhan keluarga misalnya obat- obatan, sandang pangan. Masyarakat ini sangat bergantung pada hutan untuk memenuhi kebutuhan hidup mereka. Mereka juga memiliki kearifan lokal dalam mengolah bahan pangan tersebut sebelum dikonsumsi. Permasalahan dalam penelitian ini: Bagaimana Deskripsi pemanfaatan tumbuhan hutan sebagai sumber pangan lokal dan proses pengolahan tumbuhan hutan secara tradisional oleh Masyarakat Desa Oben Kecamatan Nekamese Kabupaten Kupang. Tujuan Penelitian ini adalah Untuk mendeskripsikan pemanfaatan tumbuhan hutan sebagai sumber pangan lokal dan proses pengolahan tumbuhan hutan secara tradisional oleh Masyarakat Desa Oben Kecamatan Nekamese Kabupaten Kupang.

\section{Bahan dan Metode}

\section{Waktu dan tempat}

Penelitian dilaksanakan di Kawasan Hutan

Nunboni Desa Oben Kecamatan Nekamese Kabupaten Kupang Secara geografis terletak pada $123^{\circ}$ 16'10.66"BT-124 ' 13'42,15"- 9 ' 15'11,78'-10o.22' 14,25". Permukaan tanah di wilayah ini umumnya berbukit-bukit, bergunung- gunung dan sebagian terdiri dari dataran rendah dengan tingkat kemiringan mencapai $45^{\circ}$ berada diantara ketinggian $150-500 \mathrm{~m} \mathrm{dpl}$, atau sekitar 10,15 persen ada di ketinggian $>500 \mathrm{~m}$ dpl dan sisanya pada ketinggian antara $0-150 \mathrm{~m}$ dpl. dan suhu rata- rata $31{ }^{\circ} \mathrm{C}$ ( Kab. Kupang dalam Angka, BPS., 2019), dilaksanakan selama 3 bulan mulai dari tanggal 24 April - 22 Juli 2020.

\footnotetext{
Alat dan Bahan

Alat yang digunakan dalam Penelitian ini adalah alat tulis untuk mencatat nama tumbuhan dan memberi nomor urut pada kertas label koran bekas, kompas sebagai alat navigasi sebagai penunjuk arahuntuk mempermudah dalam proses penelitian, rol meter. Plastik dengan berbagai ukuran (besar, sedang dan kecil) untuk mengisi sampel tumbuhan pada saat pengambilan sampel. Kertas label untuk membuat label pada tumbuhan. Buku untuk identifikasi sampel tumbuhan umbi, isolasi (lakban) untuk merekatkan specimen. Koran bekas untuk membungkus specimen sebelum diisi dalam plastik.
}

\section{Metode Penelitian}

Metode yang digunakan dalam penelitian ini adalah metode Observasi, jelajah, ekplorasi dan wawancara. Kegiatan awal yang dilakukan dengan tujuan untuk melihat dan mengetahui keadaan lokasi penelitian sebelum melakukan penelitian secara. Pengamatan awal menggunakan kompas (alat bantu) dengan penentuan titik I bagian Timur, titik II bagian barat, titik III bagian utara dan titik IV berada dibagian selatan. Penggunaan Kompas ini bertujuan untuk menentukan arah berupa sebuah panah penunjuk arah mata angin dan mempermudah penjelajahan hutan. Hutan Nunboni memiliki luas tanah 4 hektar dengan panjang dan lebar 200x200 m. Responden dipilih secara sengaja yaitu terhadap mereka yang berdasarkan informan kunci dianggap paling mengenal kebiasaan masyarakat setempat dalam memanfaatkan hutan Nunboni sebagai sumber pangan lokal. Dengan metode ini diperoleh 12 orang responden yang terdiri dari: Kepala Desa selaku pimpinan Desa; Tua Adat yang dituakan atau yang mengetahui asal usul Desa Oben dan mengetahui nama-nama dari tumbuhan hutan yang sering dijadikan sebagai sumber makanan oleh masyarakat Desa Oben; Pemilik hutan (2 orang); dan masyarakat (8 orang) sekitar Desa Oben yang mengetahui dan sering mengambil tumbuhan dari hutan untuk dijadikan makanan.

Eksplorasi dilakukan bersama dengan beberapa responden dengan menjelajahi mulai berjalan dari arah timur, ke barat, ke utara dan terakhir kearah selatan. Pada saat eksplorasi, Peneliti menggali tumbuhan hutan yang dijadikan sebagai bahan makanan lalu dibawah ke Laboratorium untuk mengamati, mengukur panjang dan lebar tumbuhan dan mencatat hal-hal yang dianggap penting dari tumbuhan hutan tersebut, seperti: ciri-ciri morfologi, aroma atau bau tumbuhan, warna tumbuhan dicocokkan dengan buku kunci. Sampel tumbuhan yang diambil berupa batang tumbuhan berdaun, buah, akar dan umbi ubi. Pada saat eksplorasi dilakukan koleksi organorgan tumbuhan berupa umbi (isinya), akar, batang, daun, buah dan biji dengan menggunakan alat pemotong yaitu gunting, pisau atau parang kemudian memasang label pada spesimen, nomor, tanggal koleksi, nama daerah, kemudian dibungkus dengan koran bekas dan dimasukan ke dalam kantong plastik. Jumlah sampel tumbuhan yang harus dikoleksi untuk setiap jenis berjumlah 3-4 sampel. Kegiatan identifikasi dapat dilakukan pada laboratorium dengan melihat semua ciri morfologi yang mencolok pada suatu jenis tumbuhan dengan yang lain. Sehingga berdasarkan perbedaan tersebut akan disusun suatu kunci identifikasi dicocokkan dengan buku kunci Identifikasi dan membagi tumbuhan dalam berbagai jenis kedalam tingkat taksonnya masing-masing.

Data yang diperoleh dianalisan secara deskriptif, dengan proses mencari dan menyusun data secara sistematis. Melakukan tabulasi data dalam bentuk tabel 
seperti data jenis-jenis tumbuhan yang dijadikan sebagai sumber makanan lokal, data cara memanfaatkan tumbuhan pangan lokal, bagian atau organ tumbuhan yang digunakan. Jenis-jenis tumbuhan tersebut ditunjukan dalam bentuk gambar. Data-data tersebut adalah data yang diperoleh dari hasil wawancara dan catatan lapangan. Deskripsi sampel merupakan pelukisan atau penggambaran dengan kata-kata tentang batasan, ruang lingkup, dan sifat-sifat suatu jenis tumbuhan. Isi deskripsi berupa habitus, ciri-ciri umbi, bunga, biji, buah, nama umum dan nama lokal. Hasil analisis sampel berupa ciri dan sifat ciri dari tumbuhan pangan lokal yang di manfaatkan di susun suatudeskripsi.

\section{Hasil dan Pembahasan}

\section{Jenis - Jenis Tanaman Hutan}

Desa Oben Kecamatan Nekamese Kabupaten Kupang memiliki sumber daya alam yang sangat banyak dan beragam diantaranya tumbuhan hutan yang sudah dimanfaatkan masyarakat sebagai bahan makanan (karbohidrat) untuk memenuhi kebutuhan rumah tangga. Hasil penelitian terdapat lima jenis umbi hutan yang ditemukan dan biasa dikonsumsi oleh masyarakat Desa Oben Kecamatan Nekamese Kabupaten Kupang.

Tabel 1. Jenis -jenis tanaman hutan yang dimanfaatkan sebagai bahan pangan

\begin{tabular}{|c|c|c|c|c|}
\hline No & Nama Ilmiah & $\begin{array}{l}\text { Nama } \\
\text { daerah }\end{array}$ & $\begin{array}{l}\text { Nama } \\
\text { Umum }\end{array}$ & $\begin{array}{l}\text { Proses } \\
\text { pengolahan }\end{array}$ \\
\hline 1. & $\begin{array}{l}\text { Discorea } \\
\text { alata } \mathrm{L} .\end{array}$ & Uwi & Uwi & $\begin{array}{l}\text { rebus,kukus,g } \\
\text { oreng dan } \\
\text { dibuat sayur }\end{array}$ \\
\hline 2. & $\begin{array}{l}\text { Dioscorea } \\
\text { esculenta L. }\end{array}$ & $\begin{array}{l}\text { Lakfui } \\
\text { berduri }\end{array}$ & Gembili & $\begin{array}{l}\text { rebus, } \\
\text { kukus,goreng, } \\
\text { dijemur buat } \\
\text { tepung }\end{array}$ \\
\hline 3. & $\begin{array}{l}\text { Dioscorea } \\
\text { hispida D. }\end{array}$ & $\begin{array}{l}\text { Lakfui } \\
\text { tidak } \\
\text { berduri }\end{array}$ & Gadung & $\begin{array}{l}\text { bersihkan } \\
\text { racunnya dgn } \\
\text { abu, direndam } \\
\text { air } 2 \text { hari } \\
\text { dibersihkan, } \\
\text { jemur goreng }\end{array}$ \\
\hline 4. & $\begin{array}{l}\text { Dioscorea } \\
\text { pentaphylla }\end{array}$ & $\begin{array}{l}\text { Umbi } \\
\text { Katak/U } \\
\text { bi hutan }\end{array}$ & $\begin{array}{l}\text { Tombor } \\
\text { eso }\end{array}$ & $\begin{array}{l}\text { rebus, kukus, } \\
\text { bakar }\end{array}$ \\
\hline 5. & $\begin{array}{l}\text { Amorphophall } \\
\text { us } \\
\text { campanulatus }\end{array}$ & $\begin{array}{l}\text { Umbi } \\
\text { Suweg }\end{array}$ & Mae & $\begin{array}{l}\text { bersihkan } \\
\text { racunnya dgn } \\
\text { abu, direndam } \\
\text { air } 2 \text { hari } \\
\text { dibersihkan, } \\
\text { jemur goreng }\end{array}$ \\
\hline
\end{tabular}

Deskripsi tanaman hutan yang dimanfaatkan untuk pangan lokal.

\section{Dioscorea alata $\mathrm{L}$.}

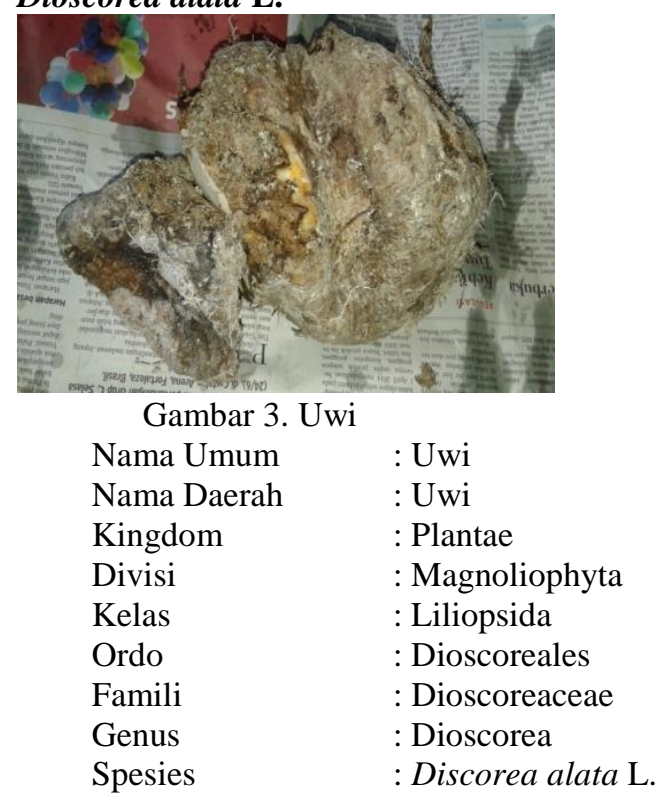

\section{Deskripsi:}

Uwi atau Dioscorea alata L. adalah anggota Dioscorea yang paling banyak dijumpai di Indonesia. Jenis ini juga telah lama dikenal oleh masyarakat pedesaan. Tanaman uwi ini dapat tumbuh di berbagai jenis tanah bahkan di daerah pegunungan yang kering dan berkapur. Panjang uwi sekitar $80 \mathrm{~cm}$, daging umbi bagian tengah berwarna merah cerah serta kulit dalamnya berwarna merah atau cokelat kekuningan. Kulitnya kasar berserabut, bentuknya tidak beraturan berwarna ungu kecokelatan karena warna diikuti warna kulit kayu. Berdasarkan hasil penelitian sebelumnya Sumber karbohidrat yang lain sebagian besar berupa umbiumbian, antara lain jenis-jenis uwi-uwian spp), ubi kayu atau ohu ai, ubi jalar atau, keladi-keladi, talas, dan kentang, yang hampir semuanya dapat dipenuhi dari dalam atau paling tidak dari daerah-daerah sekitar memang sering dipergunakan sebagai bahan pangan di daerah kering seperti daerah Nusa Tenggara dan Maluku (Sastrapradja et al., 1977). Jenis-jenis ada yang sengaja ditanam oleh masyarakat seperti ubi kayu, ubi jalar, uwiuwian, dan kentang, ada pula yang tumbuh secara alamiah di hutan. sesuai dengan RePPProT tahun 1989 bahwa kombinasi dari curah hujan yang rendah, kecepatan angin yang tinggi dan radiasi sinar matahari yang tinggi membuat NTT merupakan wilayah yang paling kering di Indonesia (Monk, 1997). Berdasarkan hasil wawancara dengan penduduk setempat, padi pada awalnya bukan merupakan makanan pokok mereka. 


\section{Dioscorea esculenta $\mathrm{L}$.}

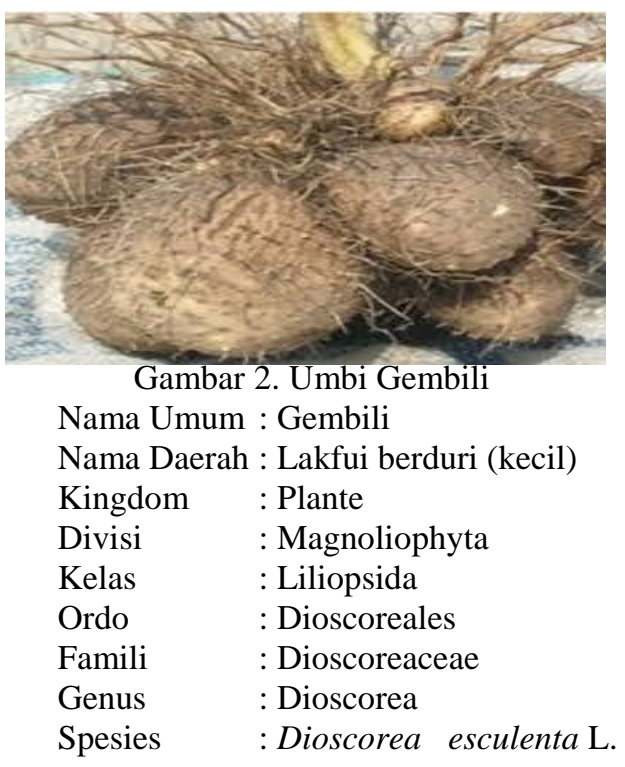

\section{Deskripsi:}

Gembili dapat tumbuh di tanah datar sampai ketinggian $700 \mathrm{~m}$, tanah berpasir dan merupakan tumbuhan tahunan atau perennial, tumbuhan merambat umbi yang masih mentah jika dimakan rasanya gatal, tetapi jika direbus enak dan agak lekat seperti ketan.Memiliki akar serabut, warna ulit akar cokelat, permukaan kasar, memiliki umbi akar, memiliki duri akar. Memiliki batang berbentuk bulat, permukaan batang licin, membelit, kulit berwarna hijau, Batang gembili memiliki duri berukuran kecil yang terletak pada samping ketiak daun. Memiliki daun tunggal, tangkai bulat, bangun jantung, panjang daun sekitar $8-9 \mathrm{~cm}$, lebar sekitar $9 \mathrm{~cm}$, pangka 1 berlekuk, ujung meruncing, tulang daun menjari, tepi daun rata, daging daun tipis, warna hijau permukaan kasar. Penelitian sebelumnya jenis-jenis yang dimanfaatkan oleh masyarakat Dusun Blidit kabupaten Sikka NTT sebagai sumber karbohidrat kurang lebih sebanyak 12 jenis. Dari keduabelas jenis tersebut padi merupakan salah satu yang didatangkan dari luar NTT (sebagian besar dari Maros, Sulawesi Selatan) untuk memenuhi hampir seluruh kebutuhan masyarakat. Hal ini dapat dimengerti karena wilayah Nusa Tenggara secara umum yang relatif kering bukanmerupakan daerah yang cocok untuk bertanam padi. Gembili merupakan umbi keluarga Dioscorea yang memiliki kelebihan dapat tumbuh di bawah tegakan hutan tanpa perlakuan khusus, sehingga budidayanya dapat dilakukan secara mudah (Ariyanti. E.E., 2010).

Gembili dapat diolah menjadi keripik dan tepungnya sesuai untuk produksi kue dan roti. Keunggulan yang lain dari umbi gembili adalah tinggi karbohidrat dan mengandung senyawa bioaktif. Terdapat beberapa senyawa bioaktif seperti polisakarida larut air (PLA), dioscorin dan diosgenin yang dapat dimanfaatkan bagi kesehatan tubuh. Kandungan senyawa bioaktif tersebut dapat berfungsi sebagai immunomodulator, pencegah penyakti metabolik (hiperkolesterolemia, dislipidemia, diabetes dan obesitas) peradangan dan kanker (Prabowo et al., 2014).

\section{Dioscorea hispida D.}

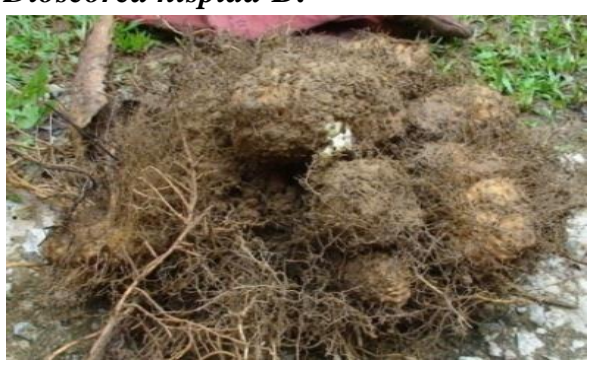

Gambar 4. Umbi Gadung

Nama Umum : Gadung

Nama Lokal : Lakfui tidak berduri (Besar)

Kingdom : Plantae

Divisi : Magnoliophyta

Kelas : : Liliopsida

Ordo : : Dioscoreales

Famili : Dioscoreaceae

Genus : Dioscorea

Spesies $\quad$ : Dioscorea hispida D.

\section{Deskripsi:}

Ubi hutan berbatang merambat dan memanjat, panjangnya mencapai 5-20 m. Arah rambatannya selalu berputar ke kiri (melawan arah jarum jam, jika dilihat dari atas). Ciri khas ini penting untuk membedakannya dari gembili yang memiliki penampilan mirip namun batangnya berputar ke kanan. Batangnya kurus ramping, setebal $0,5-1 \mathrm{~cm}$, tidak ditumbuhi duri, hijau keabuabuan. Memiliki akar serabut, kulit berwarna cokelat, permukaan kasar. Batang berbentuk bulat, permukaan batang licin, membelit, kulit berwarna hijau. Hasil penelitian Ariyanti. E.E., 2010 ditemukan 12 jenis bahan pangan dari hutan akan tetapi jenis Dioscorea tidak ditemukan, karena desa oben berada di wilayah timor Barat mempunyai iklim kering dan curah hujan Sumbersumber karbohidrat dari jenis Dioscorea sebenarnya cukup berpotensi untuk dikembangkan oleh pemerintah dan masyarakat setempat agar ketergantungan terhadap beras tidak menjadi mutlak. Selain itu kondisi iklim di Nusa Tenggara Timur yang relatif kering lebih cocok untuk pengembangan jenis-jenis umbi-umbian untuk budidaya lebih lanjut. 


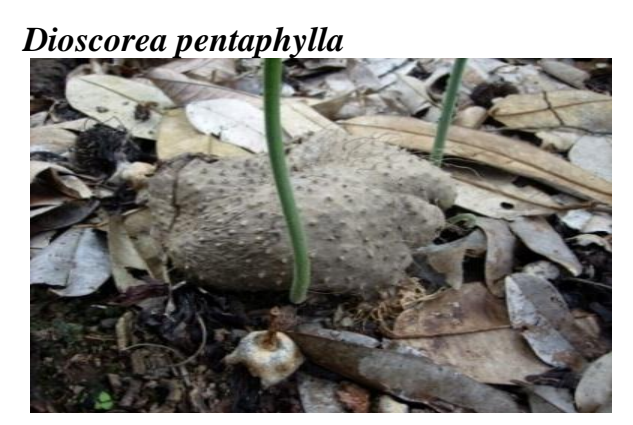

Gambar 5. Umbi Tomboreso

Nama Umum : Tomboreso

Nama Lokal : Ubi Hutan/umbi katak

Kingdom : Plantae

Divisi : Magnoliophyta

Kelas : : Liliopsida

Ordo : : liliales

Famili : : Dioscoreaceae

Genus : Dioscorea

Spesies : Dioscorea pentaphylla

\section{Deskripsi:}

Umbi ini merupakan tumbuhan semusim, tumbuh melilit, berwarna cokelat muda atau cokelat kehijauan, berduri, diameter 0,3-06 $\mathrm{cm}$. Umbi berbentuk bulat panjang dengan serabut akar yang halus. Daging umbi berwarna putih, kuning dan kadang-kadang terlihat bercak ungu, tidak bergetah, keras tapi jika diremas hancur seperti pasir. Memiliki akar serabut, akar tua berwarna cokelat, sedangkan akar muda berwarna putih bening, permukaan kasar. Memiliki Batang Berbentuk bulat, permukaan batang kasar, membelit, kulit berwarna hijau. Memilki daun tunggal, berseling, tulang daun menyirip, lebar. Proses pengambilannya di gali dan cara tumbuh merambat dan berwarna hijau pada permukaan umbinya berwarna putih susu dan isi umbinya berwarna putih, berlendir dan harus dibakar atau direbus baru bisa dikonsumsi. Sumber-sumber karbohidrat non padi tersebut sebenarnya cukup berpotensi untuk dikembangkan oleh pemerintah dan masyarakat setempat agar ketergantungan terhadap beras tidak menjadi mutlak. Selain itu kondisi iklim di Nusa Tenggara Timur yang relatif kering lebih cocok untuk pengembangan jenis-jenis umbi-umbian untuk budidaya lebih lanjut.

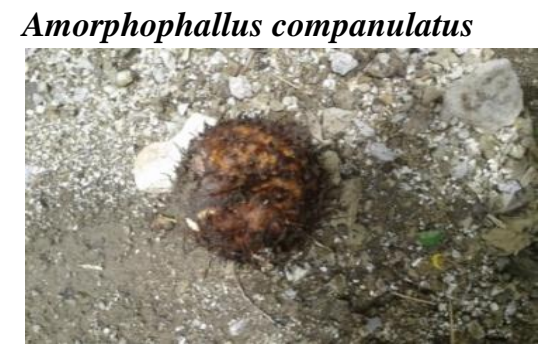

Gambar 6. Umbi Suweg

$\begin{array}{ll}\text { Nama Umum } & \text { : Umbi Suweg } \\ \text { Nama Lokal } & \text { : Mae } \\ \text { Kingdom } & \text { : Plantae } \\ \text { Divisi } & \text { : Magnoliophyta } \\ \text { Kelas } & \text { : Liliopsida } \\ \text { Ordo } & \text { : Arales } \\ \text { Famili } & \text { : Araceae } \\ \text { Genus } & \text { : Amerphophallus } \\ \text { Spesies } & \text { : Amorphophallus campanulatus }\end{array}$

\section{Deskripsi:}

Suweg adalah tanaman yang masih berkerabat dekat dengan bunga bangkai raksasa. Suweg dapat tumbuh baik pada berbagai jenis tanah termasuk tanah kapur, tanah merah, tanah lempung, tanah hitam, ataupun tanah berpasir, merupakan tumbuhan tahunan atau perennial. Suweg mempunyai tangkai daun tunggal yang sering sekali dianggap batang yang tumbuh tegak dan lunak dan berwarna hijau berbelang-belang putih permukaan tangkai daun suweg kasar bila diraba, tangkai daun pada ketinggian tertentu dapat mencapai $1,5 \mathrm{~m}$. Pada umumnya batang suweg terbagi atas tiga cabang sekunder dan akan bercabang lagi sekaligus menjadi tangkai helai daun.

\section{Manfaat Tumbuhan Hutan yang ditemukan bagi Masyarakat Desa Oben}

Hutan merupakan hal yang tidak terpisahkan dari pola kehidupan masyarakat, semua hampir tergantung pada hutan. Karena kedekatannya dengan hutan sekitar yang berada di sekitar kawasan hutan maka hidupnya bergantung pada berbagai barang dan jasa hutan. Ketergantungan masyarakat tersebut tidak jauh dari pola kehidupan masyarakat yang bermukim disekitar hutan, karena hutan menyediakan beraneka macam bahan makanan seperti sayur-sayuran mulai pucuk hingga akar, umbi-umbian, madu, bahan obat-obatan dan juga bahan bangunan rumah. Sesuai hasil wawancara dengan responden, diketahui bahwa ubi hutan yang terdapat di dalam hutan Nunboni terdapat 5 jenis ubi hutan yang biasa dikonsumsi oleh masyarakat setempat. $66,7 \%$ dari responden sering mengkonsumsi tumbuhan hutan dan $33,3 \%$ nya sangat jarang mengkonsumsi tumbuhan hutan. Masyarakat juga mengatakan bahwa yang menjadi dasar mereka mengkonsumsi tumbuhan hutan tersebut karena tumbuhan hutan disukai / digemari akan tetapi umbi hutan juga bisa menggantikan bahan makanan pokok pada saat persedian beras/jagung menipis yakni pada saat musimmusim kemarau yang berkepanjangan.

Biasanya organ atau bagian dari ubi hutan yang dikonsumsi oleh masyarakat Desa Oben adalah bagian umbinya (isinya). Berdasarkan hasil penelitian beberapa Ahli bahwa dalam umbi uwi, gembili, gadung, dan tomboreso terdapat kandungan nutrisi seperti karbohidrat protein, energi, lemak, vitamin artinya uwi, gembili, 
gadung, dan tomboreso aman dikonsumsi sehari-hari; Umbi suweg memiliki kandungan glukomannan yang cukup tinggi, glukumannan adalah polisakarida yang tersusun atas glukosa yang dapat dijadikan sebagai suplemen pangan, sedangkan daun, batang, akar dan bunganya tidak bisa dimanfaatkan atau dikonsumsi karena sebagian dari organ tumbuhan tersebut berduri dan ada yang gatal. Mereka mengkonsumsi tumbuhan hutan sebagai makanan tambahan atau sampingan saja karena menurut mereka tumbuhan ubi hutan tidak bisa dijadikan sebagai bahan makanan pokok, ubi hutan hanya sebagai bahan makanan tambahan saja, selain itu ubi hutan hanya bisa dipanen dimusim-musim tertentu yaitu musim kemarau sekitar bulan juli, agustus, september dan oktober, karena menurut para responden kalau bukan pada musim-musim kemarau di panen dan dikonsumsi maka ubi hutan tidak akan matang (noeh) jika di rebus ataupun dibakar, dan bahkan akan terasa sangat gatal dan berlendir. Ubi yang rasanya gatal dan berlendir akan mengakibatkan orang yang mengkonsumsi bisa pusing dan bahkan sampai mabuk. Selain itu, 58,3\% dari masyarakat Desa Oben mempercayai bahwa mengkonsumsi ubi hutan juga bisa mencegah timbulnya penyakit dalam tubuh.

\section{Proses pengolahan tumbuhan hutan sebagai pang secara tradisional}

Berdasarkan informasi yang didapat dari para Responden, berikut ini akan dijelaskan proses pengolahan bahan pangan dari hutan dilakukan secara tradisional, yaitu:

\section{Uwi (Dioscorea alata L.)}

Umbi uwi dibersihkan dari tanah yang masih melekat dan langsung dikupas kulitnya, pengupasan kulit harus cukup tebal. Daging uwi yang sudah dikupas di cuci bersih, setelah itu dipotong dengan ukuran sedang. Daging uwi yang sudah dicuci bersih bisa diolah menjadi uwi rebus, uwi kukus, uwi goreng, kolak uwi, kolak bubur uwi dan sayur uwi. Proses olahan uwi rebus dan uwi kukus merupakan cara pengolahan uwi yang paling sederhana. Daging uwi yang sudah di potong, di cuci lagi lalu di masukkan dalam dandang, air melebihi uwi dalam dandang tujuannya agar uwi dalam dandang tidak hitam, setelah itu di masak sampai matang, karena rasa uwi dominan tawar, sehingga untuk memberi rasa pada umbi uwi rebus/kukus biasanya ditambahkan garam, selanjutnya setelah uwi benar-benar matang diturun dari perapian lalu air uwi yang masih ada dibuang dan uwi siap disantap. Olahan uwi goreng hampir sama dengan uwi rebus/kukus, karena uwi goreng terlebih dahulu di rebus / kukus sampai setengah matang, uwi yang sudah matang ditiris airnya. Daging uwi yang sudah ditiris di masukkan dalam adonan terigu (bisa juga tanpa terigu) yang telah disiapkan, di beri gula sedikit (tergantung selera manis), selanjutnya daging uwi digoreng dan siap dihidangkan untuk dikonsumsi. Uwi dapat diolah sebagai bahan sayur berkuah tanpa atau dengan santan, yang dicampur dengan bahan-bahan lain yaitu labu kuning, kacang panjang, bayam, kangkung, jantung pisang atau disesuaikan dengan selera. Bumbu yang digunakan juga bervariasi. Apabila diolah tanpa santan maka bumbu yang digunakan adalah bawang merah, bawang putih, cabai merah, kemiri, garam, dan masako/ajino moto. Namun, jika diolah dengan santan maka bumbu-bumbunya adalah lada, asam, kunyit, bawang merah, bawang putih, kemiri, masako dan garam.

\section{Gembili (Dioscorea esculenta L.)}

Umbi gembili bisa diolah dalam berbagai jenis masakan yaitu direbus/dikukus, dibuat kripik umbi gembili dan tepung gembili. Proses olahannya, umbi gembili dibersihkan dari tanah yang masih melekat dan langsung dikupas kulitnya, pengupasan kulit harus cukup tebal, dicuci hingga bersih setelah itu dipotong dengan ukuran sedang atau kecil. Umbi rebus/kukus, daging gembili yang sudah dibersihkan dan dipotong, direbus/dikukus dengan menggunakan dandang, ditaburi sedikit garam dan setelah matang di turunkan dari perapian dan langsung bisa di santap. Ubi gembili juga bisa diolah menjadi tepung gembili, cara pembuatan tepung umbi gembili ini cukup mudah. Daging umbi gembili dipotong atau diiris kecil-kecil, lalu dijemur sampai kering, umbi yang sudah kering ditumbuk dengan lesung, lalu umbi yang sudah ditumbuk di saring dan hasilnya akan menjadi tepung, tepung ubi gembili ini bisa dibuat untuk kue-kue tradisional.

\section{Gadung (Dioscorea hispida D.)}

Umbi gadung mempunyai kadar racun yang cukup tinggi, apabila dikonsumsi secara langsung dapat menjadi racun yang sangat fatal bagi kesehatan manusia. Untuk menghilangkan racun tersebut dapat dilakukan dengan cara yaitu: pengolahan dengan abu atau kapur, umbi gadung dibersihkan dari tanah yang masih melekat dan langsung dikupas kulitnya, pengupasan kulit harus cukup tebal. Setelah dikupas umbi langsung dipotong tipis-tipis. Hasil potongan dicampur dengan abu atau kapur. Pencampuran abu atau kapur dengan potongan-potongan umbi dilakukan pada keranjang berayam daun tuak/lontar, kemudian diremas-remas sampai cairan racun itu keluar. Selanjutnya umbi diperam selama $2 \times 24$ jam diatasnya diberi pemberat agar umbi tetap tertekan. Setelah diperam, umbi yang bercampur dengan abu atau kapur itu dijemur sampai kering. Umbi yang telah kering kemudian dibersihkan dengan cara merendamnya kedalam air mengalir selama $2 \times 24$ jam. Setelah itu umbi gadung sudah siap dikukus dan kemudian dijemur sampai kering lalu digoreng dan disantap. 


\section{Tomboreso (Dioscorea pentaphylla)}

Menurut masyarakat Desa Oben, umbi tomboreso hanya bisa direbus, dikukus atau dibakar. Proses pengolahannya adalah direbus/dikukus dan dibakar.Cara mengolah umbi tomboreso yang akan direbus/dikukus adalah pertama, umbi tomboreso dibersihkan dari tanah yang masih melekat dan langsung dikupas kulitnya, pengupasan kulit harus cukup tebal. Kedua, setelah dikupas umbi langsung dipotong sedang dan di kukus atau direbus sampai matang, sebelum diangkat umbi tomboreso terlebih dahulu ditaburi garam, setelah itu umbi diangkat lalu ditiriskan dan umbi tomboreso siap dikonsumsi.

Sedangkan ubi tomboreso yang diolah dengan cara dibakar tidak membutuhkan proses yang panjang. Umbi tomboreso setelah diambil dari hutan, dibersihkan dari tanah yang masih melekat dan langsung dibakar sampai matang. Umbi tomboreso yang sudah matang dikeluarkan dari api lalu dikupas dan siap dikonsumsi. Pengolahan ini yang paling sederhana. Menurut hasil Nurbaya, peneliti gizi dari Politekes Mamuju, Sulawesi Barat, dibanding beras atau singkong, nilai gizi ubi hutan sebenarnya lebih rendah tetapi kandungan serat dan kalsium tinggi. Total energi sikapa $100 \mathrm{Kal}$, karbohidrat $23,5 \mathrm{gr}$, protein $0.9 \mathrm{gr}$ dan lemak 0,3. Kandungan energi memang sedikit, lebih rendah dibandingkan singkong. Namun kandungan serat jauh lebih tinggi 2,1 gr, dibandingkan singkong hanya 0,9 dan beras 0,2. Kandungan serat tinggi inilah yang memperlambat penyerapan gula dalam darah. Sangat baik untuk penderita diabetes mellitus. Sumba Timur, NTT beralih ke ubi hutan, sebagai pengganti beras dan jagung karena gagal panen. Mereka mengkonsumsi ubi hutan sambil menunggu beras bantuan pemerintah.

Menurut Nurbaya, kelebihan ubi ini mudah diperoleh di hutan, karena bisa tumbuh dalam segala musim. Bahkan, di musim kering tanaman ini bisa bertahan. Budidayapun relatif mudah.

\section{Suweg (Amorphophallus companulatus)}

Umbi Suweg adalah salah satu umbi yang mempunyai lendir yang gatal jika dipegang ataupun dikonsumsi. Untuk menghilangkan lendir pada umbi suweg tersebut dapat dilakukan dengan cara yaitu pengolahan dengan abu, umbi suweg dibersihkan dari tanah yang masih melekat dan langsung dikupas kulitnya, pengupasan kulit harus cukup tebal. Setelah dikupas umbi langsung dipotong tipis-tipis. Hasil potongan dicampur dengan abu. Pencampuran abu dengan potonganpotongan umbi dilakukan pada keranjang berayam daun tuak / lontar, kemudian diremas-remas sampai cairan lendir keluar. Selanjutnya umbi diperam selama 3-4 hari diatasnya diberi pemberat agar umbi tetap tertekan. Setelah diperam, umbi yang bercampur dengan abu itu dijemur sampai kering. Umbi yang telah kering kemudian dibersihkan dengan cara merendamnya kedalam air mengalir selama 2 hari. Setelah itu umbi suweg dikukus atau direbus sampai setenga matang. Setelah setengah matang di matikan apinya dan ditiris untuk mengeluarkan airnya, selanjutnya umbi yang sudah ditiris diiris tipistipis, umbi yang sudah diiris dijemur selama 2-3 hari sampai benar-benar kering, selanjutnya umbi yang sudah kering di goreng lalu diberi bumbu (tergantung selera) dan tahap terakhir kripik siap di hidangkan serta siap dikonsumsi.

\section{Kesimpulan}

Berdasarkan hasil penelitian yang telah dilakukan di Desa Oben Kecamatan Nekamese Kabupaten Kupang dapat disimpulkan bahwa telah diperoleh : Ada lima jenis umbi hutan yang ditemukan dan biasa dikonsumsi oleh masyarakat Desa Oben Kecamatan Nekamese Kabupaten Kupang. Kelima jenis umbi hutan yaitu Dioscorea alata L; Dioscorea esculenta L; Dioscorea hispida D; Dioscorea pentaphylla, Amorphophallus companulatus.Dari kelima jenis umbi hutan yang ditemukan memiliki manfaat sebagai sumber makanan lokal bagi Masyarakat Desa Oben, selain itu juga umbi hutan dimanfaatkan untuk membuat kripik dan tepung yang dimanfaatkan untuk membuat kue-kue tradisional. Pada umumnya masyarakat Desa Oben mengolah umbi hutan masih secara tradisional, dengan cara dibakar atau direbus. Selain direbus dan di bakar, Masyarakat ini juga memanfaatkan umbi hutan untuk dibuat kripik dan tepung umbi yang akan dibuat sebagai bahan kue tradisional.

\section{Ucapan terima kasih}

Terima kasih kepada Kementerian Pendidikan dan Kebudayaan atas dukungan dana yang diberikan dalam bentuk penelitian dosen pemula da Rektor UPG 45 NTT yang telah mendukung baik moril maupun materil dalam pelaksanaan penelitian ini. Pemerintah kabupaten Kupang, Kepala Desa Oben Camat Nekamese.

\section{Referensi}

A., Arief. (1994). Hutan, Hakekat dan Pengaruhnya terhadap Lingkungan. Jakarta.Penerbit Yayasan Obor Indonesia. Jakarta.

Anonymous (2015). Tumbuhan Liar Sebagai Sayuran. Jurusan Biologi Fakultas Matematika dan Ilmu Pengetahuan Alam Universitas Halu Oleo Kendari.

Apriyantono, et al. (2009). Analisa Pangan. Bogor: IPB Press. 
Bungin, M. \& Burhan (2006). Metodologi Penelitian Kuantitatif, Jakarta: Kencana Prenada Media Group.

Djurumana, Gerson ND., \& Tigor Butarbutar (2008). Prospek Pengembangan Hasil Hutan Bukan Kayu Berbasis Agroforestri untuk Meningkatkan dan Diversifikasi Pendapatan Masyarakat di Timor Barat. Balai Penelitian Kehutanan Kupang. Jurnal Info Hutan, V (1): 53-62

Ariyanti, E.E. (2010). Pemanfaatan Berbagai Jenis Tumbuhan Sebagai bahan Pangan Di Dusun Blibit, Desa Egon, Kecamatan Waigete, Kabupaten Sikka Propinsi NTT. UPT Balai Konservasi Tumbuhan Kebun Raya Purwodadi LIPI. Penelitian hayati Edisi Khusus : 4A(55-58)

Hardiyanto, B. (2020). Pandemi, Pangan dan Pemanfaatan Hutan Rakyat. Lembaga Penelitian dan Pengembangan Sumberdaya dan Lingkungan Hidup. (LPPSLH). Opini Mahasiswa Doktor UGM. https://www.mongabay.co.id/2020/06/ 18/pandemi-pangan-dan-pemanfaatanhutan-bagi-rakyat/

Hermawan, A. (2014). Peran teknologi dan kelembagaan usaha tani konservasi dalam optimalisasi lahan kering. Pengembangan Inovasi Pertanian, 7(2), 83-94.

Id, A. A., Soelaeman, Y., \& Abdurachman, A. (2003). Keragaan dan dampak penerapan sistem usaha tani konservasi terhadap tingkat produktivitas lahan perbukitan Yogyakarta. Jurnal litbang pertanian, 22(2), http://203.190.37.42/publikasi/p3222032.pdf

Idjudin, A. A. (2011). Peranan konservasi lahan dalam pengelolaan perkebunan. Jurnal sumberdaya lahan, 5(2). http://balittanah.litbang.pertanian.go.id/ind/doku mentasi/lainnya/jsdl-vol5no2-05-a\%20abas.pdf

Irawan R., H A Oramahi \& Gusti Hardiansyah (2020). Pemanfaatan Tumbuhan Sebagai Bahan Pangan Sekitar Kawasan Hutan Desa Sedahan Jaya Kecamatan Suka Dana Kabupaten Kayong Utara. 8(3): 552-565 https://jurnal.untan.ac.id/index.php/jmfkh/article/ view/41730

Juliana, Linda R. \& Mukarlina (2013). Pemanfaatan Tumbuhan Yang Berpotensi Sebagai Sumber Pangan di Gunung Peramas Desa Pangkalan Buton Kecamatan Sukadana Kabupaten Kayong Utara. Jurnal Protobiont. 2 (3): 117-
121.

https://jurnal.untan.ac.id/index.php/jprb/article/vi ew/3877

Liza, H. A. Oramahi \& Lolyta Sisillia (2020). Jenis Tumbuhan Yang Dimanfaatkan Sebagai Sumber Pangan Oleh Masyarakat Desa Jawai Laut Kecamatan Jawai Selatan Kabupaten Sambas. Jurnal Hutan Lestari, 8 (2) : 315 - 324. https://jurnal.untan.ac.id/index.php/jmfkh/article/ view/40052

Monk KA De Fretes \& G. Reksodihardjo -Lilley (1997). The Ecology of Nusa Tenggara and Maluku (The Ecology of Indonesia Series Volume V). Periplus Edition. Singapore.

Nurbaya \& W. Candra (2015). Ubi Hutan Ini Beracun Tetapi Banyak Manfaat. Jurnal Poltekes Mamuju. https://www.mongabay.co.id/2015/05/09/ubihutan-ini-beracun-tetapi-banyak-manfaat/

Prabaningrum, H., Nugroho, A. S., \& Kaswinarni, F. (2018). Keanekaragaman Tumbuhan Yang Berpotensi Sebagai Bahan Pangan di Cagar Alam Gebugan Semarang. Jurnal Biologi dan Pembelajarannya, 5(2), 26-31. file:///C:/Users/ASUS/Downloads/12580Article\%20Text-6079-1-10-20181107.pdf

Romana, Burhanuddin \& Thamrin E. (2018). Tumbuhan Sumber Pangan yang Dikonsumsi Oleh Masyarakat Pada Tembawang Pak Kuning Disengah Temila. Jurnal Hutan Lestari. 6(4): 869874. 24

Setiawan, H., \& Qiptiyah, M. (2014). Kajian etnobotani masyarakat adat suku moronene di Taman Nasional Rawa Aopa Watumohai. Jurnal Penelitian Kehutanan Wallacea,3(2), 107-117. https://www.jurnal.balithutmakassar.org/index.ph $\mathrm{p} /$ wallacea/article/view/38

Sastrapradja S, NW Soetjipto, S Danimihardja \& R Soejono (1997). Ubi-ubian LBN-LIPI, Bogor.LBN 7 SDE 40 Proyek Sumberdaya Ekonomi

Sumarlin, D., Dirhamsyah, M., \& Ardian, H. (2015). Identifikasi Tumbuhan Sumber Pangan di Hutan Tembawang Desa Aur Sampuk Kecamatan Sengah Temila Kabupaten Landak. Jurnal Hutan Lestari, 4(1). https://jurnal.untan.ac.id/index.php/jmfkh/article/ view/14481

Sunarti, S. R., \& Djarwaningsih, T. (2007). Tumbuhan Berpotensi Bahan Pangan di Daerah Cagar Alam Tangale. Jurnal Biodiversitas, 8(2), 88-91. 